\title{
COVID-19 MATERIALS WASTE MANAGEMENT TECHNIQUES AND SUSTAINABILITY IN RIVERS STATE, NIGERIA
}

\author{
Onugha, Augustine Chimeebere \\ Department Of Geography And Environmental Studies \\ Ignatius Ajuru University Of Education \\ Port Harcourt, Rivers State Nigeria
}

\begin{abstract}
The rising challenges of sustainably handling contagious material leftovers necessitated an investigation into covid-19 materials waste management techniques and sustainability in Rivers State, south-south Nigeria. The quantitative study adopted the correlational research design. A sample of 245 respondents (comprising 40 medical practitioners, 60 public health officials, 90 waste workers, 10 RIWAMA staff, and 45 environmentalists) participated in the study. A 30item 3 environmental experts validated 4-point scale instrument titled "COVID-19 material waste management and sustainability Inventory" (COMWMSI) with a reliability coefficient of 0.835 was used to elicit data analyzed using regression analysis. The study revealed that: the technique for stowing, collection and disposal of gloves residues statistically and significantly contributed $28.6 \%$, $29.0 \%$, and $25.5 \%$ respectively, to sustainability in Rivers State, Nigeria. While the technique for stowing, collection and disposal of masks residues statistically and significantly contributed $26.4 \%$, $23.4 \%$, and $23.2 \%$ respectively, to sustainability in Rivers State, Nigeria. The study recommended among others that: regulatory authorities should sensitize the populace on proper waste management techniques (like safe handling, storing, collection and disposal including disinfection of trash bins) for materials like gloves and masks thereby, helping reduce the impending threats to human and environmental health.
\end{abstract}

Keywords: COVID-19 materials, waste management techniques, sustainability, Rivers State.

\section{INTRODUCTION}

COVID-19 is a global pandemic and one of the respiratory diseases with an unprecedented and novel strain which has a yet to be ascertained skyrocketing or rapidly increasing infectious, contagious or transmittable rate devoid of ethnic, racial, cultural, status, social, and educational borders. This makes COVID-19 a global crisis with a ravaging effect on humans in almost all the countries of the world [1], which has overstretched the existing health facilities and personnel even at tertiary levels [2]. [3] noted that the difference in the mode of transmitting this epidemiologic or viral disease from bodily fluids produced during physical contact, breathing, coughing, and sneezing has necessitated individuals use of specific materials. Thus, COVID-19 materials is conceptualized as the personal protective equipment (PPE) like masks (i.e. face and eye) and punctureresistant gloves specified and used as an infection preventive guidance for both the infected and uninfected persons.

Incidentally, the COVID-19 pandemic has heightened the need for the wearing of these specified PPEs, some of which are non-reusable, non-washable, and non-transferable, thereby exposing potential gaps or breaches for infection spread from the discarded materials [4]. Averting this behooves on medical practitioners, public health officials, and environmentalists issuing guidelines on the method of disposal of the waste likely to be generated after using the materials (i.e. PPE) by especially infected individuals or households either on quarantine or freely moving in the society [3]. However, compliance to this directive raises a great concern in a society like ours with poor waste management culture where waste from materials (like gloves and masks) considered as infectious residues are arbitrarily discarded in 


\section{International Journal of Engineering Applied Sciences and Technology, 2020 Vol. 5, Issue 1, ISSN No. 2455-2143, Pages 737-746 \\ Published Online May 2020 in IJEAST (http://www.ijeast.com)}

unapproved places (like roadsides, bushes, etc.) rather than in standard trash bins located in designated sites [5].

Consequently, ensuring that used PPE (i.e. waste) are discarded using procedures where there will be minimal contact and harm on others [6], is extremely important so that the post-COVID-19 experience would not be mesmerizing and catastrophic with another disease outbreak that would worsen and truncate the expected economic recovery plans. Additionally, citizenry adherence to established guidelines entails authorities ably or proficiently regulating the technique for waste management (conceptualized as the safe stowing, collection, and disposal of waste without any environmental malfeasance). Equally, guidance or regulation (like: storage in sealed bags, collection using protective equipment, and disposal via combustion or incineration) for managing (i.e. sorting and discarding) infectious residues [7]. This will forestall waste mishandling thereby reducing exposure of legal waste workers and illegal workers (like human and animal scavengers) to diseases or infections [8].

Generally, waste is an unwanted, exhausted or finished, and expired liquid, solid or gaseous material, substance or product [9], that needs to be swiftly or quickly discarded due to its hazardous, dangerous and smelly or stinking nature of the emissions or oozes that negatively impacts on human health, biodiversity sustenance, and environmental serenity. However, the method adopted for specialized collection and final disposal of waste from materials like masks and gloves should be based or centered on enlightenment or education on local safe disposal options (like incineration, compositing, etc.) that are financially maintainable, technically feasible, socially acceptable and environmentally friendly [10]. Alongside, readily available, accessible, and affordable to the populace whose health or wellbeing and cleanliness or hygiene is extremely paramount to realizing sustainable development.

Deductively, the basis for upholding waste management is sequel to attaining sustainability (conceptualized as practices and innovations like technology that boosts human and environmental health, revenue, and aesthetics) in the storage, collection and disposal of used COVID-19 materials (like gloves and masks) is geared towards protecting the society. Regrettably, this seemingly ascribed public health order is and has been deficient as it overtime does not consider the hygiene and wellbeing of the waste workers who are managing these risky or harmful materials for other citizens. Although, waste management services are regarded as essential services during or outside crisis period (like COVID-
19). However and most unfortunate, is that the existing and even the new enhanced insurance package provided for essential service personnel (like health workers) does not in any way cover waste workers who in the true sense are responsible for evacuating the medical waste generated by health workers. This is the crux of the study and the point of departure would be tackling issues that may warrant negligence to waste disposal and further disease spread.

\section{STATEMENT OF THE PROBLEM}

COVID-19 is a viral and highly contagious disease that presupposes on individuals wearing specific disposable or one-use materials that its residues if mismanaged could aggravate the cycle of infection that it initially intends to prevent. Also, across locations the responsibility of managing waste is vested on certain authorities who deploys financial resources and organizational structure in enlightening and setting measures for collecting, handling or treating, regulating and disposing waste [10]. Over the years, the derision or denigration of waste workers has intensified indiscriminate refuse disposal in unapproved sites and in defiance to the trash bins or receptacles (where available) for the collection and removal by persons perceived to be at the lowest ebb of the society. In view of this, the disposal of infectious residues of gloves and masks heightens a buildup of disease prevalence cycle as a problem that would severely impact the health of both waste workers (whether municipal or private) and the reckless populace. Thereby, triggering post-COVID-19 massive security, economic and developmental crisis.

Although, personal protective equipment (like disposable gloves and masks) are introduced as infection prevention measures and materials to reduce the risk of viral transmission. However, the likelihood that the residues, remains, relics or leftovers from used PPE are highly transmittable necessitates the adoption of good and special collection and disposal of these waste from homes, hospitals, ambulances, isolation centers, laboratories, and vehicles. This will free individuals, waste workers, health personnel, and the populace from the COVID-19 disease, which is a problem that has weakened the family, society, and government regulatory institution (like Rivers State Waste Management Agency, RIWAMA) capacity (socially, economically, and technologically) to adopt novel strategy like disinfecting or decontaminating homes, waste containers, delivery trucks, public places, and other facilities towards the efficient management of this novel virus.

Furthermore, the pedestrian, unscientific and subjective views propagated by individuals, waste 


\section{International Journal of Engineering Applied Sciences and Technology, 2020 Vol. 5, Issue 1, ISSN No. 2455-2143, Pages 737-746 \\ Published Online May 2020 in IJEAST (http://www.ijeast.com)}

workers, and regulators like RIWAMA on the duration for storing or stowing, collecting and discarding household and public waste including the interval for sterilizing trash bins and places. Rather than adopting an empirically-backed timely collection and disposal of sorted and segregated waste due to the perceived cost implication is indeed antithetical to the attainment of effective regulation and management of waste. Thus, awareness and emphasis on sustainability underlies individuals and regulators, and the society realizing the social, economic, and health benefits from waste operations even during the COVID-19 pandemic. It is based on this context and premise that this study attempts to examine COVID-19 materials waste management techniques and sustainability in Rivers State, Nigeria.

Specifically, the purposes of this study were to determine:

i. the relationship between the stowing of gloves residues and sustainability in the study area.

ii. the relationship between the collection of gloves residues and sustainability in the study area.

iii. the relationship between the disposal of gloves residues and sustainability in the study area.

iv. the relationship between the stowing of masks residues and sustainability in the study area.

v. the relationship between the collection of masks residues and sustainability in the study area.

vi. the relationship between the disposal of masks residues and sustainability in the study area.

The following research questions guided this study:

1. What is the relationship between the technique for stowing of gloves residues and sustainability in the study area?

2. What is the relationship between the technique for collection of gloves residues and sustainability in the study area?
3. What is the relationship between the technique for disposal of gloves residues and sustainability in the study area?

4. What is the relationship between the technique for stowing of masks residues and sustainability in the study area?

5. What is the relationship between the technique for collection of masks residues and sustainability in the study area?

6. What is the relationship between the technique for disposal of masks residues and sustainability in the study area?

\section{SCOPE OF THE STUDY}

The study focused on investigating COVID-19 materials waste management techniques and sustainability. In terms of geographic scope the study was conducted in Rivers State, Nigeria. While in terms of content scope, the study would consider medical practitioners, and public health officials managing the COVID-19 pandemic. Including the waste workers handling and evacuating the infectious residues. Furthermore, the independent variables are COVID19 materials (via masks and gloves) and waste management techniques (via stowing, collection, and disposing) while the dependent variable is sustainability (via health, revenue, and aesthetics).

\section{THE STUDY AREA}

The study was conducted in Rivers State south-south Nigeria with a population of 5,198,716 [11], and projected population of 7,043,800 [12]. It lies between latitudes $4^{0} 45^{1} \mathrm{~N}$ and longitudes $6^{0} 50^{1} \mathrm{E}$ including a total area of $11,077 \mathrm{~km}^{2}$ (i.e. 4,277 sq mi), and density of $468 / \mathrm{km}^{2}$ (i.e. $1,210 / \mathrm{sq} \mathrm{mi}$ ). The study area is bounded by states like Bayelsa and Delta, Abia and Akwa-Ibom, and Imo in the East, West and North respectively, while the Atlantic ocean is situated at the southern boundary of the state (see Fig. 1). 


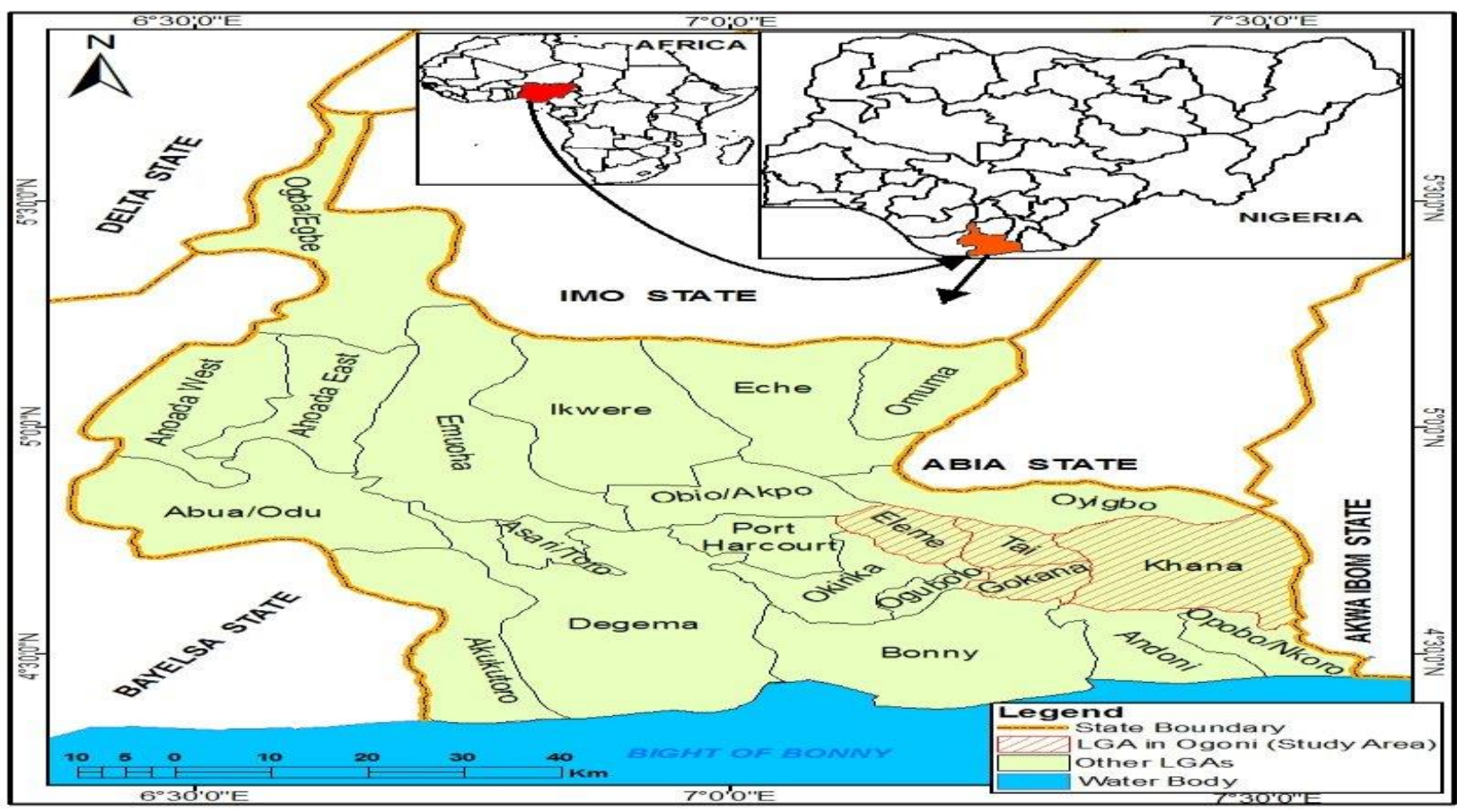

Fig.1: Rivers State showing the Local Government Areas. Inset Nigeria with Rivers State in red Source: Nigerian Local Government Administrative Map (2020).

Furthermore, the mean monthly temperature ranges between $25 \hat{\mathrm{A}}^{\circ} \mathrm{C}$ to $28 \hat{\mathrm{A}}^{\circ} \mathrm{C}$ [13]. The relief is the freshwater, mangrove swamps, and coastal sand ridges zone with poor and low-lying drainage that is seriously impacted by the heavy rainfall or wet season that last not less than 330 days and between $3,420 \mathrm{~mm}$ and $7,300 \mathrm{~mm}$, which makes almost all the riverine Local Government Areas (LGAs) of Akuku-Toru, Abua/Odual, Asari-Toru, Degema, Okrika, Ogu/Bolo, Bonny, Andoni and Opobo to be flooded at one time of the year or another [14]. Also, the vegetation supports the traditional occupation of farming in crops like plantain, banana, maize, okra, cassava and yam including economic trees (like oranges, mango, avocado pie, coconut, oil palm, and raffia palm), hunting and fishing activities. However, this occupation has transited to modern occupation like oil exploration, civil service, public service, trading, and other services.

\section{METHODOLOGY}

Research Design: This quantitative study adopted the correctional research design. The correlational research establishes the relationship between two or more variables in order to find out the effect of the independent variable (i.e. covid-19 materials and waste management) and the dependent variable (i.e. sustainability) involved in the interaction or association [15].

Population for the Study: The population for the study comprised of all the frontline medical practitioners, and public health officials in the two tertiary hospitals i.e. University of Port Harcourt Teaching Hospital (UPTH) and Rivers State University Teaching Hospital (RSUTH) managing the COVID-19 pandemic in Rivers State. Also, the waste workers or contactors evacuating the waste, operational personnel in Rivers State Waste Management Agency (RIWAMA), and environmentalists constituted the population for this study.

Sample and Sampling Technique: A sample of 245 respondents (i.e. medical practitioners, public health officials, waste workers, regulatory personnel and environmentalists) participated in the study. The study adopted a four-phased multistage sampling technique. Firstly, random sampling technique was used in the selection of 40 medical practitioners (i.e. 20 each from UPTH and PSUTH). In the second phase, 60 public health officials (i.e. 20 each from UPTH, RSUTH, and Rivers State Ministry of Health) were selected using random sampling technique.

Thirdly, purposive sampling was used in the selection of 30 waste contracting companies managing waste in 


\section{International Journal of Engineering Applied Sciences and Technology, 2020 Vol. 5, Issue 1, ISSN No. 2455-2143, Pages 737-746 \\ Published Online May 2020 in IJEAST (http://www.ijeast.com)}

Port Harcourt metropolis. Then in the fourth phase, random sampling technique was used in the selection of 90 waste workers (i.e. 3 each) from the 30 waste contacting companies. In the fifth phase, 10 operational personnel of RIWAMA were randomly selected. While in the sixth and final phase, random sampling technique was used in the selection of 45 environmentalists (i.e. 15 each from IAUE, RSU, and UNIPORT). This constituted a sample of 205 respondents (via 40 medical practitioners, 60 public health officials, 90 waste workers, 10 RIWAMA staff, and 45 environmentalists) that was used for the study.

Instrumentation: Data for this study was sourced from both primary and secondary data (through text books, articles, manuals, documents, magazines, dictionaries, and other publications). The primary data was sourced from a self-structured 40-item instrument titled "COVID-19 material waste management and sustainability Inventory" (COMWMSI). The COMWMSI instrument was patterned after a four point rating scale of "Very High Extent" (VHE, 4 Points), "High Extent" (HE, 3 Points), "Low Extent" (LE, 2 Points), and "Very Low Extent" (VLE, 1 Point). Furthermore, the COMWMSI instrument consist of three sections. Section A elicited the demographics of the respondents (i.e. medical practitioners, public health officials, waste workers, RIWAMA personnel, and environmentalists) Section B comprised of the item variables of COVID-19 materials (via gloves and masks), and waste management (via stowing, collection, and disposal). While Section C comprised of item variables on sustainability (via health, revenue, and aesthetics).

Validation of Instrument: The face and content validity of the COMWMSI instrument was determined by three (3) environmental experts (i.e. 1 each from Ignatius Ajuru University of Education (IAUE), Rivers State University (RSU), and University of Port Harcourt (UNIPORT)). These validates were provided with topic, objectives and research questions of this study for their expert comments, suggestions, and

VI. views which were eventually incorporated to enhance the validity of the COMWMSI instrument.

Reliability of the Instrument: The reliability or internal consistency of the COMWMSI instrument was ascertained using Cronbach Alpha $\left(\mathrm{r}_{\mathrm{a}}\right)$ method. In doing this 50 copies of the COMWMSI instrument was administered to 50 respondents (via 10 medical practitioners, 10 public health officials, 20 waste workers, and 10 environmentalists) in Imo State (which was not used for the study). Then 50 copies of the COMWMSI instrument were administered to the respondents and upon completion was retrieved, coded and analyzed using the Cronbach Alpha $\left(\mathrm{r}_{\mathrm{a}}\right)$ method to obtain a reliability coefficient of 0.835 . The obtained reliability coefficient necessitated the use of the COMWMSI instrument for administration.

Method of Data Collection: The researcher (in company of two research assistants) adopted the faceto-face direct delivery technique for the administration of the COMWMSI instrument to all the 205 respondents (i.e. medical practitioners, public health officials, waste workers, regulatory personnel and environmentalists). Also, the study used virtual technique i.e. technology-aided devices like emails and WhatsApp (where it is feasible as the realistic option for getting at the respondents that cannot be reached physically). In whichever technique the instrument was administered to the respondents as received or retrieved from same source. Out of the 245 copies of the COMWMSI instrument administered to the respondents, only 227 copies (representing approximately $93 \%$ return rate) were validly retrieved and used for the analysis.

Method of Data Analysis: The collected data was scored, tabulated, coded, and analyzed using multiple linear regression analysis to answer the research questions. All statistical computations were done using the Statistical Package for Social Science (SPSS) 22.0.

\section{RESULTS}

Research Question 1: What is the relationship between the technique for stowing of gloves residues and sustainability in the study area?

Table 1: Summary of Multiple Linear Regression Analysis on the relationship between the technique for stowing of gloves residues and sustainability in the study area

\begin{tabular}{|l|l|l|l|l|l|l|}
\hline Source & $\begin{array}{l}\text { Sum of } \\
\text { Squares (SS) }\end{array}$ & Df & Mean Square & F. Ratio & P-value & Remark \\
\hline Regression & 1427.955 & 2 & 713.977 & 44.943 & $.000^{\mathrm{b}}$ & $\mathrm{S}$ \\
\cline { 1 - 4 } Residual & 3558.547 & 224 & 15.886 & & & \\
\hline Total & 4986.502 & 226 & & & & \\
\hline
\end{tabular}


Multiple $R\left(r_{p}\right)=.535^{a}$
R. Square $\left(r^{2}\right)=.286$
Adjusted $R^{2}=.280$
Standard Error of Estimate $=3.98577$

a. Dependent Variable: Sustainability

b. Predictors: (Constant), Stowing, Gloves

Table 1 shows that the use of the technique for stowing of gloves residues to predict the sustainability in Rivers State Nigeria yielded a coefficient of multiple regression $\mathrm{R}$ (rp) of 0.535 and multiple regression square $\left(\mathrm{R}^{2}\right)$ of 0.286 This also shows that $\mathrm{F}$ is 44.943 which is significant at $\mathrm{P}<0.05$ because the value of $\mathrm{P}$ is less than 0.05 . This shows that the technique for stowing of gloves residues accounted or contributed for 28.6 percent in sustainability in Rivers State Nigeria. Therefore, the technique or method for stowing or storing gloves residues or remains contributed approximately $29 \%$ of the variance to sustainability in Rivers State Nigeria.

Research Question 2: What is the relationship between the technique for collection of gloves residues and sustainability in the study area?

Table 2: Summary of Multiple Linear Regression Analysis on the relationship between the technique for collection of gloves residues and sustainability in the study area

\begin{tabular}{|c|c|c|c|c|c|c|}
\hline Source & Sum of Squares (SS) & Df & Mean Square & F. Ratio & P-value & Remark \\
\hline Regression & 1444.677 & 2 & 722.338 & \multirow[t]{3}{*}{45.684} & \multirow[t]{3}{*}{$.000^{\mathrm{b}}$} & \multirow[t]{3}{*}{$\mathrm{S}$} \\
\hline Residual & 3541.825 & 224 & 15.812 & & & \\
\hline Total & 4986.502 & 226 & & & & \\
\hline $\begin{array}{l}\text { Multiple R } \\
\text { R. Square (1 } \\
\text { Adjusted R } \\
\text { Standard Er }\end{array}$ & $\begin{array}{l}. .538^{\mathrm{a}} \\
.290 \\
83 \\
\text { f Estimate }=3.97640\end{array}$ & & & & & \\
\hline
\end{tabular}

a. Dependent Variable: Sustainability

b. Predictors: (Constant), Collection, Gloves

Table 2 shows that the use of the technique for collection of gloves residues to predict the sustainability in Rivers State Nigeria yielded a coefficient of multiple regression R (rp) of 0.538 and multiple regression square $\left(\mathrm{R}^{2}\right)$ of 0.290 This also shows that $F$ is 45.684 which is significant at $P<0.05$ because the value of $\mathrm{P}$ is less than 0.05 . This shows

that the technique for collection of gloves residues accounted or contributed for 29.0 percent in sustainability in Rivers State Nigeria. Therefore, the technique or method for collection or gathering gloves residues or remains contributed approximately $29 \%$ of the variance to sustainability in Rivers State Nigeria.

Research Question 3: What is the relationship between the technique for disposal of gloves residues and sustainability in the study area?

Table 3: Summary of Multiple Linear Regression Analysis on the relationship between the technique for disposal of gloves residues and sustainability in the study area

\begin{tabular}{|c|c|c|c|c|c|c|}
\hline Source & $\begin{array}{l}\text { Sum of } \\
\text { Squares (SS) }\end{array}$ & Df & Mean Square & F. Ratio & P-value & Remark \\
\hline Regression & 1273.081 & 2 & 636.541 & \multirow[t]{3}{*}{38.397} & \multirow[t]{3}{*}{$.000^{\mathrm{b}}$} & \multirow[t]{3}{*}{$\mathrm{S}$} \\
\hline Residual & 3713.421 & 224 & 16.578 & & & \\
\hline Total & 4986.502 & 226 & & & & \\
\hline $\begin{array}{l}\text { Multiple R ( } \\
\text { R. Square (r } \\
\text { Adjusted } \mathrm{R}^{2} \\
\text { Standard Err }\end{array}$ & $\begin{array}{l}. .505^{\mathrm{a}} \\
.255 \\
49 \\
\text { f Estimate }=4.07\end{array}$ & & & & & \\
\hline
\end{tabular}

a. Dependent Variable: Sustainability 


\section{International Journal of Engineering Applied Sciences and Technology, 2020 \\ Vol. 5, Issue 1, ISSN No. 2455-2143, Pages 737-746 \\ Published Online May 2020 in IJEAST (http://www.ijeast.com)}

b. Predictors: (Constant), Disposal, Gloves

Table 3 shows that the use of the technique for disposal of gloves residues to predict the sustainability in Rivers State Nigeria yielded a coefficient of multiple regression $\mathrm{R}$ (rp) of 0.505 and multiple regression square $\left(\mathrm{R}^{2}\right)$ of 0.255 This also shows that $\mathrm{F}$ is 38.397 which is significant at $\mathrm{P}<0.05$ because the value of $\mathrm{P}$ is less than 0.05 . This shows that the technique for disposal of gloves residues accounted or contributed for 25.5 percent in sustainability in Rivers State Nigeria. Therefore, the technique or method for disposal or discarding of gloves residues or remains contributed approximately $26 \%$ of the variance to sustainability in Rivers State Nigeria.

Research Question 4: What is the relationship between the technique for stowing of masks residues and sustainability in the study area?

Table 4: Summary of Multiple Linear Regression Analysis on the relationship between the technique for stowing of masks residues and sustainability in the study area

\begin{tabular}{|c|c|c|c|c|c|c|}
\hline Source & $\begin{array}{l}\text { Sum of } \\
\text { Squares (SS) }\end{array}$ & Df & Mean Square & F. Ratio & P-value & Remark \\
\hline Regression & 1315.380 & 2 & 657.690 & \multirow[t]{3}{*}{40.130} & \multirow[t]{3}{*}{$.000^{\mathrm{b}}$} & \multirow[t]{3}{*}{$S$} \\
\hline Residual & 3671.122 & 224 & 16.389 & & & \\
\hline Total & 4986.502 & 226 & & & & \\
\hline $\begin{array}{l}\text { Multiple R } \\
\text { R. Square (r } \\
\text { Adjusted R }\end{array}$ & $\begin{array}{l}=.514^{\mathrm{a}} \\
.264 \\
57\end{array}$ & & & & & \\
\hline
\end{tabular}

a. Dependent Variable: Sustainability

b. Predictors: (Constant), Stowing, Masks

Table 4 shows that the use of the technique for stowing of masks residues to predict the sustainability in Rivers State Nigeria yielded a coefficient of multiple regression $\mathrm{R}$ (rp) of 0.514 and multiple regression square $\left(R^{2}\right)$ of 0.264 This also shows that $F$ is 40.130 which is significant at $\mathrm{P}<0.05$ because the value of $\mathrm{P}$ is less than 0.05 . This shows that the technique for stowing of masks residues accounted or contributed for 26.4 percent in sustainability in Rivers State Nigeria. Therefore, the technique or method for stowing or storing masks residues or remains contributed approximately $26 \%$ of the variance to sustainability in Rivers State Nigeria.

Research Question 5: What is the relationship between the technique for collection of masks residues and sustainability in the study area?

Table 5: Summary of Multiple Linear Regression Analysis on the relationship between the technique for collection of masks residues and sustainability in the study area

\begin{tabular}{|l|l|l|l|l|l|l|}
\hline Source & $\begin{array}{l}\text { Sum of } \\
\text { Squares (SS) }\end{array}$ & Df & Mean Square & F. Ratio & P-value & Remark \\
\hline Regression & 1167.089 & 2 & 583.545 & 34.224 & $.000^{\mathrm{b}}$ & $\mathrm{S}$ \\
\hline Residual & 3819.413 & 224 & 17.051 & & & \\
\hline Total & 4986.502 & 226 & & & \\
\cline { 1 - 2 } Multiple R $\left(\mathrm{r}_{\mathrm{p}}\right)=.484^{\mathrm{a}}$ & & & \\
R. Square $\left(\mathrm{r}^{2}\right)=.234$ & & & \\
Adjusted $\mathrm{R}^{2}=.227$ \\
Standard Error of Estimate $=4.12928$
\end{tabular}

a. Dependent Variable: Sustainability

b. Predictors: (Constant), Collection, Masks 


\section{International Journal of Engineering Applied Sciences and Technology, 2020 Vol. 5, Issue 1, ISSN No. 2455-2143, Pages 737-746 \\ Published Online May 2020 in IJEAST (http://www.ijeast.com)}

Table 5 shows that the use of the technique for collection of masks residues to predict the sustainability in Rivers State Nigeria yielded a coefficient of multiple regression $\mathrm{R}$ (rp) of 0.484 and multiple regression square $\left(\mathrm{R}^{2}\right)$ of 0.234 This also shows that $\mathrm{F}$ is 34.224 which is significant at $\mathrm{P}<0.05$ because the value of $\mathrm{P}$ is less than 0.05 . This shows that the technique for collection of masks residues accounted or contributed for 23.4 percent in sustainability in Rivers State Nigeria. Therefore, the technique or method for collection or gathering masks residues or remains contributed approximately $23 \%$ of the variance to sustainability in Rivers State Nigeria.

Research Question 6: What is the relationship between the technique for disposal of masks residues and sustainability in the study area?

Table 6: Summary of Multiple Linear Regression Analysis on the relationship between the technique for disposal of gloves residues and sustainability in the study area

\begin{tabular}{|l|l|l|l|l|l|l|}
\hline Source & $\begin{array}{l}\text { Sum } \\
\text { Squares (SS) }\end{array}$ & Df & Mean Square & F. Ratio & P-value & Remark \\
\hline Regression & 1159.150 & 2 & 579.575 & 33.920 & $.000^{\mathrm{b}}$ & $\mathrm{S}$ \\
\cline { 1 - 3 } Residual & 3827.352 & 224 & 17.086 & & & \\
\hline Total & 4986.502 & 226 & & & \\
\cline { 1 - 2 } Multiple R $\left(\mathrm{r}_{\mathrm{p}}\right)=.482^{\mathrm{a}}$ & & & \\
R. Square $\left(\mathrm{r}^{2}\right)=.232$ & & & \\
Adjusted $\mathrm{R}^{2}=.226$ \\
Standard Error of Estimate $=4.13357$
\end{tabular}

a. Dependent Variable: Sustainability

b. Predictors: (Constant), Disposal, Masks

Table 6 shows that the use of the technique for disposal of masks residues to predict the sustainability in Rivers State Nigeria yielded a coefficient of multiple regression $\mathrm{R}$ (rp) of 0.482 and multiple regression square $\left(R^{2}\right)$ of 0.232 This also shows that $F$ is 33.920 which is significant at $\mathrm{P}<0.05$ because the value of $\mathrm{P}$ is less than 0.05 . This shows that the technique for disposal of masks residues accounted or contributed for 23.2 percent in sustainability in Rivers State Nigeria. Therefore, the technique or method for disposal or discarding of masks residues or remains contributed approximately $23 \%$ of the variance to sustainability in Rivers State Nigeria.

\section{DISCUSSION OF FINDINGS}

The result in Table 1 revealed that the technique or method of stowing or storing of gloves residues statistically and significantly contributed to sustainability in Rivers State Nigeria. This finding is consistent with the assertion of [7] and [16] that used and residues of gloves need to be stowed, stored or dropped in clean waste bag that should be sealed, closed, tied or knotted before they are removed from the patient's room or dump sites in order to avoid its residues or remains from infecting the heath of other humans.
The result in Table 2 revealed that the technique or method of collection or gathering of gloves residues statistically and significantly contributed to sustainability in Rivers State Nigeria. This finding is in agreement with [17] who stated that the practices and procedures or techniques adopted in the collection of COVID-19 materials waste like gloves residues are geared towards enhancing the safety and health of waste workers or employees managing, sorting and treating such infectious waste. This according to [8], would prevent waste mismanagement by this means reducing the rate of infection or exposure of waste workers including scavengers to diseases, illnesses or viruses.

The result in Table 3 revealed that the technique or method of disposal or discarding of gloves residues statistically and significantly contributed to sustainability in Rivers State Nigeria. This findings aligns with the position of [18] that compliance to the specialized precautions and guidance on the disposal of infectious residues of gloves (i.e. COVID-19 materials) stowed or stored in closed tightly sealed or tied tear-proof plastic bags or bio bin prior to disposed of in the residual waste collection container is to safeguard or protect the environment from pollution, improve human health, and provide revenue or income (otherwise 


\section{International Journal of Engineering Applied Sciences and Technology, 2020 Vol. 5, Issue 1, ISSN No. 2455-2143, Pages 737-746 \\ Published Online May 2020 in IJEAST (http://www.ijeast.com)}

sustainability) for those or firms involved in the collection and recycling of residual waste.

The result in Table 4 revealed that the technique or method of stowing or storing of masks residues statistically and significantly contributed to sustainability in Rivers State Nigeria. This finding is in agreement with previous finding by [19] that properly and safely handling and stowing or storing hazardous or infectious residues of masks in a tightly closed or sealed waste bag kept shortly in a temporary storage area before final disposal is a vital and an effective emergency response that will improve human health and environmental sustainability even during crisis period like COVID-19.

The result in Table 5 revealed that the technique or method of collection or gathering of masks residues statistically and significantly contributed to sustainability in Rivers State Nigeria. This finding is consistent with the views of [18] that the integration of specialized method for collecting infectious residues or waste of materials (like masks) used by COVID-19 infected persons is geared towards forestalling the transmission of the sticky or gluey fluids and other secretions which could be disastrous to the health of waste workers and others who come in contact with such waste material. This justifies [7] assertion of disinfecting or sanitizing the trash containers before they are emptied or discarded in order to avoid spread of diseases (like COVID-19).

The result in Table 6 revealed that the technique or method of disposal or discarding of masks residues statistically and significantly contributed to sustainability in Rivers State Nigeria. This finding aligns with [20] and [21] who states that safe and effective management (via: storage in sealed bag, collection using protective eyewear and other equipment, separation from domestic garbage, transportation, treatment and disposal either discretely or incinerated) of infectious residues of materials like masks is a sound environmental guideline that would minimize hazards to human health and maximize sustainability.

\section{CONCLUSION}

The study concludes that the technique for managing waste (via stowing, collection, and disposal) from COVID-19 materials (like gloves and masks) has the propensity to relatively and jointly contribute to sustainability through improved health or wellbeing, revenue or income, and aesthetics in Rivers State, Nigeria. Therefore, the integration of modern technique, method or procedure in managing the waste or residues from hazardous and infectious materials (like gloves and masks) during this COVID-19 pandemic is an exigent, crucial and most important palliative, disaster response and public service that would positively impact human, economic and environmental health or wellbeing (otherwise sustainability) in Rivers State, Nigeria.

Based on the findings, the following suggestions were made:

1. The Waste Management authority should enforce the immediate cessation of the practice of scavenging and other forms of waste sorting at dumpsites due to the unpredictability of the state of health of the creators or litterers of such waste materials like gloves and masks.

2. Regulatory authorities like RIWAMA should sensitize the populace on proper waste management techniques (like safe handling, storing, collection and disposal including disinfection of trash bins) for materials like gloves and masks thereby, helping reduce the impending threats to human and environmental health.

3. RIWAMA should ensure that going forward, all artisanal waste collectors and private waste contractors and its personnel must be made to compulsorily use personal protective equipment (PPE) and other hygienic standards prior to handling, collecting and discarding masks, gloves and other infectious materials residues.

4. The Government in conjunction with medical practitioners and health officials, should embark on the production of renewable and washable face masks made from cotton fabrics in order to reduce the incidence of discarding infectious or hazardous residues.

5. The government and waste contractors should be encouraged to provide insurance cover and hazard allowance as an incentive or stimulus package for waste workers or personnel.

6. The remains of mask and gloves should be separately stored in firmly tied doubled-bags in order to avoid glued fluids or secretions from COVID-19 patients spreading to others including waste workers.

\section{Acknowledgement}

The effort of Mrs. Chinenye Onugha in participating and leading the administration process alongside, coding the data used for this study is highly commendable and appreciated. Also, appreciation goes to Prof. Andrew Obafemi for the instructions and encouragements towards the conduct of this study. Whilst, Dr. Mrs. Beatrice Acee-Eke is highly saluted for initiating the discussions that intensified interest in the conduct of this all important research. 


\section{International Journal of Engineering Applied Sciences and Technology, 2020 Vol. 5, Issue 1, ISSN No. 2455-2143, Pages 737-746 \\ Published Online May 2020 in IJEAST (http://www.ijeast.com)}

\section{REFERENCES}

[1] B. A. Nicks and O. Wong, "Coronavirus Disease 2019 (COVID-19): A Global Crisis", Medscape, pp. 1-21, 2020.

[2] J. Wong, Q. Y. Goh, Z. Tan, S. A. Lie, Y. C. Tay, S. Y. Ng and C. R. Soh, " Preparing for a COVID19 Pandemic: A Review of Operating Room Outbreak Response Measures in a Large Tertiary Hospital in Singapore," Canadian Journal of Anaesthesia, vol. 11, No. 3, pp. 1-14, 2020.

[3] World Health Organization (WHO), " Rational Use of Personal Protective Equipment (PPE) for Coronavirus Disease (COVID-19): Interim Guidance," Geneva, Switzerland, WHO Publication, 2020. Available from: https://www.who.org/WHO/2019nCov/IPC_PPE_use/2020.3/19March 2020

[4] A. Ault, " COVID-19 Exposes Potential Gaps in PPE Training and Effectiveness ", In Medscape Medical News of Sunday, May 3, 2020.

[5] Public Health England (PHE), " COVID-19: Infection Prevention and Control Guidance ", In PHE Publications, London, UK, 2020

[6] B. M. Tompkins and J. P. Kerchberger, " Special Article: Personal Protective Equipment for Care of Pandemic Influenza Patients: A Training Workshop for the Powered Air Purifying Respirator," Anesth Analg., vol. 111, pp. 933945, 2010

[7] The European Centre for Disease Prevention and Control (ECDPC), " Guidance for Wearing and Removing Personal Protective Equipment in Healthcare Settings for the Care of Patients with Suspected or Confirmed COVID-19 ", In ECDPC Technical Report, vol 2, pp. 1-13, 2020.

[8] N. Ferronato and V. Torretta, " Waste Mismanagement in Developing Countries: A Review of Global Issues," Int J Environ Res Public Health, vol 16, No. 6, pp. 1060, 2019

[9] R. M. Yoada, D. Chirawurah and P. B. Adongo " Domestic Waste Disposal Practice and Perceptions of Private Sector Waste Management in Urban Accra," BMC Public Health, vol 14, pp. 697, 2014.

[10] H. I. Abdel-Shafy and M. S. M. Mansour, " Solid Waste Issue: Sources, Composition, Disposal,
Recycling, and Valorization," Egyptian Journal of Petroleum, vol 27, No. 4, pp. 1275-1290, 2018

[11] National Population Commission (NPC), " Federal Government of Nigeria Official Gazzette of the 2006 Census Report ", In National Population Commission Publications, Abuja, Nigeria, 2007.

[12] National Population Commission (NPC), " Projected population of states in Nigeria ", In National Population Commission Publications, Abuja, Nigeria, 2016.

[13] Encyclopedia Britannica, " History of Rivers State ", Retrieved 30 November 2014 from http//www.rvsg.

[14] K. C. ChiadikobI, A. O. Omoboriowo, O. I. Chiaghanam, A. O. Opatola and O. Oyebanji " Flood Risk Assessment of Port Harcourt, Rivers State, Nigeria," In Pelagia Research, vol 2, No. 6, pp. 287-298, 2011.

[15] O. C. Nwankwo, " Practical guide to research writing: For students of research enterprise (Revised Fifth Edition)," Uniport Publishing, Choba, 2013.

[16] The Nigeria Centre for Disease Control (NCDC), " An Update of COVID-19 Outbreak in Nigeria. Weekly Epidemiological Report,", 2020, Retrieved from http//www.ncdc.gov.ng.

[17] C. A. Ratti, " Municipal Waste Management and COVID-19," In Association of Cities and Regions for Sustainable Resource Management, pp. 1-9, 2020.

[18] S. Salehi, " Coronavirus Disease 2019 (COVID19): A Systematic Review of Imaging in 919 Patients," PMID, vol 32, No. 1, pp. 714-729, 2020.

[19] A. Pixahay, "Waste Management an Essential Public Service in the Fight to Beat COVID-19," A UN Environment Programme Publication, Geneva, Switzeland, 2020.

[20] R. Payet, " Guidelines on the Environmentally Sound Management of Biomedical and Healthcare Waste," Waste. Guidance Documents of the Basel Convention Regional Centre for Asia and the Pacific, Beijing, China, 2020.

[21] J. P. Li, D. S. Lam, Y. Chen and D. S. Ting," Novel Coronavirus Disease 2019 (COVID-19): The Importance of Recognizing Possible Early Ocular Manifestation and Using Protective Eyewear," Br J Ophthalmol., vol 104, pp. 297298, 2020. 